\section{Infeksjoner på fremmarsj}

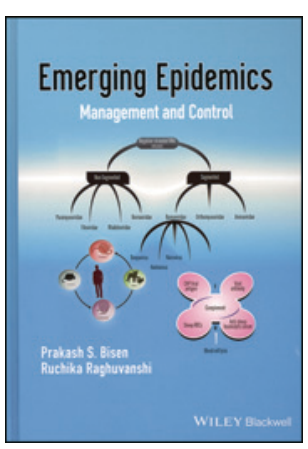

Prakash S. Bisen, Ruchika Raghuvanshi Emerging epidemics

Management and control. 736 s, tab, ill.

Chichester: Wiley-Blackwell, 2013.

Pris GBP 110

ISBN 978-1-118-39323-9

Mikrobeverdenen har til alle tider vist en enorm dynamikk og evne til stadig å tilpasse seg til endringer i omgivelsene. Opp gjennom historien har det dukket opp nye infeksjonssykdommer, og infeksjonssykdommer som tidligere nærmest har forsvunnet, dukker opp igjen - ofte med økt geografisk utbredelse. I angloamerikansk litteratur benyttes betegnelsene «emerging infections» om nye infeksjonssykdommer og «reemerging infections» om infeksjoner som dukker opp på ny. Det er særlig gjennom de siste 20 år disse infeksjonenes betydning er blitt allment anerkjent. Listen over aktuelle infeksjoner er lang. Det mest dramatiske eksemplet er hivepidemien. Andre eksempler er sarsepidemien, fugleinfluensa (H5N1epidemien) og Creutzfeldt-Jakobs sykdom. Man vet i dag mye om de faktorene som har betydning for disse infeksjonssykdommene, og det satses i økende grad på forebyggende arbeid.

Noen god, oppdatert lærebok på feltet har vi imidlertid ikke. Vil denne utgivelsen, skrevet av to indiske forfattere, fylle dette tomrommet? Jeg er redd jeg må svare benektende på dette spørsmålet. av flere grunner.

Min hovedinnvending er at den fokuserer for lite på de spesielle problemene på dette feltet. Den gir ikke noen god og bred innføring $i$ alle de faktorene som har betydning for fremveksten av de aktuelle infeksjonssykdommene - klimaendringer, forandringer i økosystemer, endringer i demografi og menneskers atferd, omlegging av husdyrhold og matproduksjon, krig og sosial uro, for bare å nevne noen. Kunnskap om disse forholdene er vesentlig for det forebyggende arbeidet.

Boken gir derimot omfattende omtaler av en rekke av de aktuelle infeksjonene, men dette finner man også i ordinære infeksjonsmedisinske lærebøker. Balansen i omtalen av de enkelte sykdommene er ikke god.

Forfatterne skriver hele 75 sider om tuberkulose og 50 sider om influensa.

Bioterrorisme fortjener ikke bortimot 70 sider. 55 sider om kontroll av mygg og andre insektvektorer er også langt mer enn en interessert infeksjonsmedisiner setter pris på.

Min konklusjon er at forfatterne formidler grei informasjon om en del aktuelle infeksjoner, som man imidlertid også vil finne andre steder. Det mangler adekvat omtale av de mange faktorene som påvirker fremveksten av disse infeksjonene, og som det er viktig å angripe. Derfor er dette ikke noen velegnet innføring i denne fascinerende delen av infeksjonmedisinen.

Stig Frøland

Overlege, Seksjon for klinisk immunologi- og infeksjonssykdommer Oslo universitetssykehus

\section{Grundig om bildediagnostikk ved nevromuskulær sykdom}

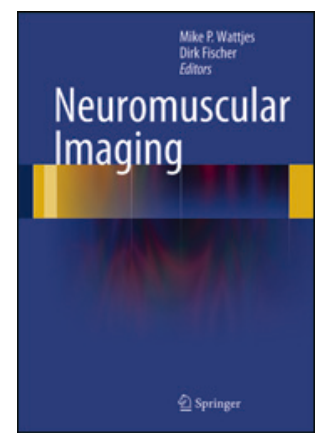

Mike P. Wattjes, Dirk Fischer, red. Neuromuscular imaging

424 s, tab, ill. Heidelberg: Springer, 2013.

Pris EUR 143

ISBN 978-1-4614-6551-5

Dette er en omfattende lærebok som omtaler et stort spekter av sykdommer som er relativt sjeldne, eller som sjelden blir utredet med bildediagnostiske metoder. Målgruppen er derfor subspesialister innen muskel- og skjelettradiologi, nevroradiologi og øre-nesehals-radiologi. Boken vil også være interessant for en del klinikere som jobber med nevromuskulære sykdommer. Forfatterne har som mål at leseren skal forstå bakgrunnen både for sykdommen og for logikken bak de radiologiske funnene.

Boken er delt opp i fem deler. Del 1 omhandler de forskjellige bildegivende modalitetene (ultralyd, CT, MR, avansert og kvantitativ MR, nukleærmedisinske metoder). Denne delen er informativ uten å gå for mye inn i tekniske detaljer, og den gir en oversikt over det man bør vite for å forstå de neste kapitlene.

Del 2 tar for seg muskelanatomi og fysiologi, og inneholder et fint atlas som viser aksiale MR-bilder av hele kroppen, der de forskjellige musklene er fargelagt og navngitt. Det siste kapitlet i denne delen tar for seg bildegjengivelse av normal aldring av muskelvev.

Del 3 handler om hereditære myopatier, og det er mange eksempler både med radiologiske, histologiske og kliniske meget illustrative bilder. Muskeldystrofier er også omtalt.

Del 4 omtaler ikke-hereditære myopatier, som inflammatoriske myopatier, toksiske og medikamentinduserte myopatier og muskelneoplasmer. Her er det, i tillegg til radiologiske og histologiske bilder, et nyttig flytskjema som viser hvordan muskulære neoplasmer skal vurderes på MR.

Del 5 tar for seg kliniske og radiologiske aspekter ved motornevronsykdommer og vurdering av perifere nerver. I dette kapitlet er det også en del intraoperative bilder.

Språket er lettfattelig engelsk og har en muntlig stil. Boken er rikt illustrert, også med fargebilder. Innholdsfortegnelsen er oversiktlig, og det finnes en liste over forkortelser som er brukt. Forkortelsene er også gjort rede for underveis i teksten, slik at undertegnede sjelden trengte å slå opp i denne listen. Hvert kapittel er bygd opp med «key points». Oppdatert litteraturliste på slutten av kapitlene, eller underveis dersom kapitlet er stort og tar for seg forskjellige temaer.

Konklusjon: Dette er et oppslagsverk som omhandler temaet «neuromuscular imaging» grundig og illustrativt. Mange vil lære en god del nytt ved å lese denne boken, og dermed være forberedt når de møter pasientene i klinisk og/eller i radiologisk avdeling. 